Katarzyna Wrzesińska

ORCID 0000-0002-5533-5540

Instytut Slawistyki Polskiej Akademii Nauk

Zakład Badań Narodowościowych (Warszawa, Polska)

katarzyna.wrzesinska@ispan.waw.pl

\title{
Zanim skrystalizował się zakres badań, czyli o rozwoju nauk o człowieku i rasach ludzkich na ziemiach polskich w drugiej połowie XIX wieku
}

\begin{abstract}
Abstrakt
Artykuł opisuje debatę polskich uczonych na temat celów i zakresu badań antropologii. Wpływ na jej przebieg i rozbieżność konkluzji miało szereg czynników. Druga połowa XIX wieku to okres początkowy w kształtowaniu się tej dyscypliny badawczej. Pierwsi antropolodzy byli lekarzami, dlatego też podnoszono znaczenie badań nad fizycznością człowieka jako gatunku i jego podziałem na rasy. Jednocześnie jednak widziano potrzebę łącznego ujmowania związków biologii z ludzką kulturą i z życiem społecznym. Temu służyć miały nauki uznawane za pomocnicze wobec antropologii fizycznej: historia, etnografia, etnologia, socjologia, językoznawstwo i archeologia. Recepcja nauki
\end{abstract}

\begin{tabular}{|c|c|c|c|c|c|}
\hline \multicolumn{2}{|c|}{$\begin{array}{l}\text { INFORMACJA } \\
\text { O PUBLIKACJI }\end{array}$} & $\begin{array}{l}\text { Ptudia } \\
\text { Tistoriae } \\
\text { cientiarum }\end{array}$ & $\begin{array}{r}\text { e-ISSN 2543-702X } \\
\text { ISSN 2451-3202 }\end{array}$ & sind & $\begin{array}{l}\text { } \\
\text { BRYLANTOWY MODEL } \\
\text { OTWARTEGO DOSTĘPU }\end{array}$ \\
\hline \multicolumn{6}{|c|}{$\begin{array}{l}\text { CYTOWANIE } \\
\text { Wrzesińska, Katarzyna 2021: Zanim skrystalizował się zakres badań, czyli o rozwoju nauk o człowieku } \\
\text { i rasach ludzkich na ziemiach polskich w drugiej połowie XIX wieku. Studia Historiae Scientiarum 20, } \\
\text { ss. 31-59. DOI: } \underline{10.4467 / 2543702 X S H S .21 .003 .14034 .}\end{array}$} \\
\hline \multicolumn{3}{|c|}{$\begin{array}{l}\text { OTRZYMANO: } 28.01 .2021 \\
\text { ZAAKCEPTOWANO: } 29.06 .2021 \\
\text { OPUBLIKOWANO ONLINE: } 13.09 .2021\end{array}$} & $\begin{array}{l}\text { POLITYKA } \\
\text { ARCHIWIZOWANIA } \\
\text { Green SHERPA/ } \\
\text { RoMEO Colour }\end{array}$ & LICENCJA & $\begin{array}{l}\text { Crossref } \\
\text { Similarity Check } \\
\text { Powered by i inhenticate }\end{array}$ \\
\hline WWW & \multicolumn{5}{|c|}{ https://ojs.ejournals.eu/SHS/; http://pau.krakow.pl/Studia-Historiae-Scientiarum/archiwum } \\
\hline
\end{tabular}


zachodniej nie przynosiła gotowych wzorców. Na jej gruncie funkcjonowało bowiem jednocześnie wiele ujęć ukształtowanych przez niezależne od siebie narodowe tradycje. Ponadto rozdział nauk o człowieku na odrębne dyscypliny jeszcze się nie dokonał. Stąd też spotykamy synonimiczność terminów takich jak antropologia, etnologia i etnografia.

Polskie piśmiennictwo naukowe i popularnonaukowe, stanowiące podstawę źródłowa niniejszego artykułu, odegrało znaczącą rolę w pogłębieniu dyskursu wokół kształtujących się nauk o człowieku. Wprowadziło problematykę antropologiczną i zainteresowało nią szeroki krag czytelników. Bez samodzielnych badań oraz recepcji nauki obcej, dokonujących się w dobie zaborów, nie byłby możliwy rozwój nauk o człowieku po 1918 roku w wolnej Rzeczypospolitej.

Słowa kluczowe: rozwój nauki polskiej w XIX w., cele $i$ zakeres badań antropologicznych, rasy lud₹kie, etnologia, etnografia, terminologia, popularyzacja wiedzy

\title{
Before the scope of research crystalized, or on the development of human sciences and studies on human races in the second half of the $19^{\text {th }}$ century on the Polish lands
}

\begin{abstract}
The article describes the debate of Polish scholars about the purposes and scope of research in the field of anthropology. A number of factors had an impact on the course of this debate and its diverse conclusions. The second half of the $19^{\text {th }}$ century marks an initial period of the development of this branch of study. First anthropologists were physicians from profession and that is why the emphasis was put on the significance of research concerning the physical aspect of humans and the division of humans into different races. At the same time, a need to combine biology with culture and social life of humans arose. This approach was to be supported with the use of sciences considered as auxiliary to physical anthropology such as history,
\end{abstract}


ethnography, ethnology, sociology, linguistics, and archeology. The reception of the Western science did not offer readymade patterns. In fact, in the West, a number of established scholarly attitudes existed simultaneously, and were shaped by independent specific national traditions. Moreover, the split of human sciences into separate disciplines had not been completed yet. Accordingly, synonymic terms such as anthropology, ethnology, and ethnography were still in use interchangeably in Poland.

Polish scholarly writings as well as works popularizing science - both are sources of material in this article - played a significant role in elaborating a way to understand the emerging human sciences. The problem of anthropology was thus introduced and a wider circle of readers became interested in it. Without independent Polish studies and without the reception of foreign research during the period of partitions in Poland, human sciences would not have developed after 1918 in the sovereign Polish Republic.

Keywords: development of Polish science in the 19th century; aims and scope of anthropological research; human races; ethnology; ethnography; terminology; popularization of knowledge

\section{Wstęp}

Celem artykułu jest ukazanie meandrów rozwoju polskiej antropologii, nie jednak w sensie instytucjonalnym, a pod kątem prób inicjowanych w celu określenia zakresu jej badań. Podjęcie analiz we wskazanym kierunku dyktowane jest potrzebą wzbogacenia wiedzy związanej z kształtowaniem się zainteresowań antropologicznych na ziemiach polskich. Ma ono również na celu ukazanie, w jaki sposób ścierały się zapatrywania badaczy, co było przyczyną różnic w opiniach oraz niejednoznaczności stosowanej terminologii, a także jakie czynniki miały wpływ na kształtowanie się wizji zadań antropologii. W przypadku polskim należy również zwrócić uwagę na recepcję nauki zachodniej. Choć polscy uczeni zajmowali się przede wszystkim antropometria, to jednak istniało przekonanie, że człowieka powinno się badać całościowo, a więc zarówno jego cechy fizyczne, jak i duchowość oraz kulturę, biorąc także pod uwagę kontekst relacji społecznych. Podstawę źródłową niniejszego artykułu stanowią dyskusje uczonych i publicystów, które znalazły swe odzwierciedlenie w ówczesnym piśmiennictwie naukowym i popularnonaukowym. Poza ośrodkiem krakowskim (Akademia Umiejętności) 
nie prowadzono jednak planowych oraz systematycznych badań i analiz z zakresu antropologii.

Choć polska antropologia miała swój wcześniejszy wileński rodowód, to dopiero rok 1856 uznaje się za datę oficjalnych jej narodzin na ziemiach polskich. Wtedy na Uniwersytecie Jagiellońskim doktor medycyny Józef Majer rozpoczął wykłady z tej dyscypliny, powstała bowiem druga w Europie (po paryskiej) Katedra Antropologii. Wraz ze śmiercią następcy Majera - Izydora Kopernickiego w 1891 r. przestała jednak ona istnieć1. Przełom XIX i XX w. był więc okresem o tyle szczególnym, że w żadnym ośrodku naukowym nie wykładano antropologii, a jedynie powołana do życia w 1874 r. Komisja Antropologiczna Akademii Umiejętności zajmowała się tą dziedziną nauki². Skupieni w niej uczeni sprecyzowali wówczas zakres badań, jaki planowano podjąć bardzo szeroki, w którym zagadnienia rozumiane przez nich jako stricte antropologiczne, a dotyczące strony fizycznej człowieka, miały zazębiać się z dociekaniami $z$ innych pół badawczych: archeologii, historii i etnologii. Jak więc pisał Józef Majer, ówczesny przewodniczący Komisji Antropologicznej (funkcjonowała ona w ramach Wydziału Matematyczno-Przyrodniczego Akademii Umiejętności), badać należało człowieka

(...) I. pod względem najdawniejszych śladów jego bytu w naszym kraju; II. pod względem jego cech fizycznych, odznaczających właściwość szczepową, plemienną i narodowa; III. pod względem właściwości jego duchowych, stosunków społecznych, zwyczajów i obyczajów³

Tak szeroko ujęty postulowany program badań antropologicznych stał się jedna z przyczyn niejasności zarówno terminologicznych, jak i związanych z pojmowaniem zakresu badań. Nazwy poszczególnych nauk o człowieku zaczęto stosować synonimicznie.

$\mathrm{Na}$ ziemiach polskich brakło odpowiednio wyposażonych muzeów i bibliotek, nie istniały też środki finansowe, które można byłoby przeznaczyć na planowe badania antropologiczne ${ }^{4}$. Samodzielne prace

1 Hołda-Róziewicz 1969, s. 649; Malinowski 1986, ss. 7-8; Bielicki, Krupiński, Strzałko 1987, ss. 4-5.

2 Majer 1874, ss. LXVI-LXXXVI.

3 Idem, s. LXVII; Lutostański 1874, ss. 190-209.

${ }^{4}$ Hołda-Róziewicz 1969, s. 649. 
podejmowali lekarze $z$ terenu zaboru rosyjskiego, m. in. Władysław Olechnowicz, Leon Dudrewicz i Kazimierz Daniłowicz-Strzelbicki ${ }^{5}$. Byli oni również, oprócz socjologów Ludwika Gumplowicza i Ludwika Krzywickiego, popularyzatorami wiedzy w wymienionych poniżej czasopismach. Uczestniczyli w tym dziele przede wszystkim antropolodzy: Izydor Kopernicki, Julian Talko-Hryncewicz, Bolesław Lutostański, Edward Loth, ale także biolodzy i zoolodzy, jak np. Józef Nusbaum, geografowie jak Wacław Nałkowski, czy historycy - m.in. Zygmunt Gloger. Polskie Towarzystwo Przyrodników im. Mikołaja Kopernika, powstałe we Lwowie w 1875 r., niewattpliwie popularyzowało wiedzę w ogóle, także za pomoca wydawanych przez siebie czasopism (Kosmos. Czasopismo Polskiego Towaryystwa Prayrodników Imienia Kopernika, Wszechswiat. Tygodnik Popularny, Poświecony Naukom Prayrodniczym). Natomiast Towarzystwo Przyjaciół Nauk Poznańskie (bo tak brzmiała jego pierwotna nazwa), funkcjonujące już od 1857 r., prowadziło co prawda istotna, ale ograniczoną w swym zakresie działalność, na marginesie której znajdowała się antropologia. Prócz wydawanych w Krakowie Rozpraw i Sprawozdań zposiedzeń Wydziatu Matematyczno-Prayrodniczego, Zbioru Wiadomości do Antropologii Krajowej, a później Materiałów Antropologiczno- Archeologicznych i Etnograficznych nie istniało żadne forum służące wymianie myśli na tematy antropologiczne (rozumiane jako ogół zagadnień związanych z naukowym poznaniem człowieka). W pismach takich jak Kwartalnik Historyczny - założony w 1887 r. we Lwowie, Lud. Organ Towarzystwa Ludoznawczego we Lwowie, wydawany od 1895 r., i warszawska Wisła. Miesiecrnike geograficzno-etnograficzny, który zaczął ukazywać się w 1887 r., a także Światowit. Rocznike poświecony archeologii przeddriejowej, wydawany w Warszawie od 1899 r., problematyka z zakresu antropologii stanowiła niewielka część objętości. Pełne tytuły wymienionych powyżej czasopism naukowych wskazywały tematykę w nich dominująca. Jedynie więc w krakowskim ośrodku naukowym pod auspicjami Akademii Umiejętności sprecyzowano zakres i cele antropologii, sporządzono też kwestionariusze, podług których należało przeprowadzać badania i pomiary (m.in. anatomiczne, fizjologiczne i statystyczne) ${ }^{6}$ oraz relacjonowano wyniki podejmowanych działań. Specyfika pism naukowych,

5 Ten okres badań antropologicznych określano jako prowincjonalny, Hołda-Róziewicz 1969, s. 649.

${ }^{6}$ Majer 1874, ss. LXXV-LXXIX. 
ukazujących się w innych ośrodkach, była odmienna. Udostępniały one swe łamy uczonym prezentującym rozmaite profile badawcze, często samodzielnie podejmującym swe dociekania, stąd i tematyka publikowanych tekstów była różnorodna, a i definicje stosowanych terminów niejednolite.

Szeroko rozumianej antropologii poświęcano też uwagę na łamach różnorodnych czasopism, głównie warszawskich, których redakcje i łamy stały się forum wymiany myśli (m.in. Biblioteka Warszawska. Pismo Pośniecone Naukom, Sztukom i Przemystowi, Wedrowiec. Pismo obejmujace podróze i myprany, połaczone z. opisem zanyczajón i obyczajón ludón cudzoziemskich; ;yciorysy stawnych cudzoziemców, powiastki i przelktady z literatury zagranicznej, wiadomości z dziedziny nauk przyrodzonych, przemystu i technologii, rozmaitości, Ateneum. Pismo Naukowe i Literackie, Przeglad Tygodniony Życia Spotecznego, Literatury i Sztuk Piekenych, Prawda. Tygodnik Polityczny, Spoteczny $i$ Literacki, Gtos. Tygodnik Literacko-Spoteczno-Polityczny). Znajdowała ona również swe odzwierciedlenie w gazetach lokalnych, przeznaczonych dla kobiet czy ludu wiejskiego oraz broszurach popularyzujących wiedzę. Nie popełni się błędu stwierdzając, że w drugiej połowie XIX w. problematyka związana z naukami o człowieku była wszechobecna. Poziom publikowanych tekstów był, rzecz jasna, dostosowany do wymogów odbiorcy, a czytelnik stykający się z różnymi czasopismami musiał wyrobić sobie własne zdanie na temat pojmowania antropologii i jej zadań. Z kolei współczesny badacz, analizując wspomniane źródła, musi zwracać uwagę na ich rodzaj (naukowe, popularnonaukowe, popularne), a przede wszystkim na kontekst wypowiedzi, ponieważ stosowane do opisu nauk terminy nie zawsze znaczyły to samo. Podobnie słowo „rasa” nie było w omawianym okresie stosowane w sposób jednoznaczny, a występowało synonimicznie z pojęciami takimi jak „lud”, szczep”, „plemię" i „naród”.

\section{Człowiek w centrum zainteresowań badawczych}

Uczynienie człowieka obiektem badań datuje się od czasów starożytnych ${ }^{7}$. Greccy uczeni nadali antropologii dwoisty charakter. Zgodnie z ludzką natura - fizyczną i duchowa, jedni, jak Arystoteles i Hipokrates, badali ludzkie ciało, drudzy, jak Platon, skupiali się na duchu

7 Popowicz 2009; Lutostański 1881, ss. 262-263; Radliński 1902. 
i moralności człowieka ${ }^{8}$. Studia nad ludzkimi rasami zapoczątkowały odkrycia geograficzne9 ${ }^{9}$ Zanim w XIX w. poczęły rozwijać się nauki przyrodnicze, wiedza o zamieszkujących świat ludach opierała się na wyobrażeniach, przesądach i częstokroć mylnych spostrzeżeniach. To zainteresowanie badawcze odzwierciedlało horyzonty poznawcze kolejnych epok, a także ograniczenia wynikające ze światopoglądu badaczy, na który dominujący wpływ wywierało chrześcijaństwo i tradycja biblijna oraz stan wiedzy na temat ludzkiego życia. Jeszcze w pierwszej połowie XIX w. dominowało przekonanie, że człowiek nie ma nic wspólnego ze zwierzęciem, że został stworzony w sposób, który przekazywała Biblia i że jest wyjątkową istota. Podejmowanie kolejnych wyzwań nie byłoby możliwe bez właściwego człowiekowi dążenia do poszerzania horyzontów i przełamywania różnorodnych barier. Jak pisał historyk Zygmunt Gloger,

Umysł ludzki w miarę rozwoju nauk, dąży coraz usilniej do zbadania przeszłości, poznania dziejów własnych. O ile człowiek w ciemnocie pograżony, nie troszczy się o ścieżki, którymi chodził przed lat tysiącem i dwoma tysiącami, o tyle oświecając się, bada, docieka (...), byle w popiołach minionych tysiącleci, wydmuchać iskierkę prawdy dla nauki, wykryć światełko dla wiedzy i dodać nowe słowo do wielkiej księgi dziejów człowieka $(. . .)^{10}$.

Mimo ograniczeń wynikających z braku własnej państwowości, uczeni polscy starali się nadążać za zdobyczami nauki światowej i rozwijać własne badania ${ }^{11}$. Świadectwo tych dążeń znajdowało swe odzwierciedlenie w publikacjach, także w językach obcych, w rozwoju prasy specjalistycznej, w powstawaniu towarzystw naukowych, w udziale w międzynarodowych wystawach i kongresach, a wreszcie w popularyzacji wiedzy ${ }^{12}$. Bez tego wysiłku nie byłby możliwy rozwój antropolo-

8 Stefanowska 1891, ss. 9-10.

9 Talko-Hryncewicz 1888, s. 548.

${ }^{10}$ Gloger 1879, s. 143.

11 Bielicki, Krupiński, Strzałko 1987, ss. 3-6.

12 Prasa polska informowała systematycznie o zjazdach antropologicznych (Hodi 1873, ss. 82-95; Kopernicki 1876; Ad.J.C. 1882a, ss. 402-403), rozwoju antropologii w ogóle, jej udziale w wystawach światowych (Stefanowska 1891, ss. 9-12). Skrzętnie 
gii i innych nauk w wolnej już Rzeczypospolitej ${ }^{13}$. W drugiej połowie XIX w. europejscy podróżnicy, kolonizatorzy i misjonarze docierali w najodleglejsze zakątki świata. Spotykana różnorodność ludzka skłaniała do zadawania pytań o jej przyczyny i uwarunkowania. Podejmowano próby dociekania początków ludzkości, podważając religijne jego wyjaśnienie. Szukano powodów, które przyczyniły się do obserwowanej niejednorodności rodu ludzkiego, zarówno pod względem fizycznym, jak i duchowym. Dzięki rozwojowi medycyny i nauk przyrodniczych oraz nowym teoriom, m.in. na temat dziejów geologicznych ziemi (Charles Lyell) i ewolucji gatunków w przyrodzie (Charles Darwin), otworzyły się perspektywy badawcze. Obalona została teoria katastrof Georges'a Cuviera ${ }^{14}$. Dzieje natury i człowieka poczęto postrzegać jako nieustającą sekwencję zmian ${ }^{15}$.

Takie ewolucjonistyczne ujęcie rodziło nowe pytania: kiedy pojawił się człowiek, jak wówczas wyglądał, czy rozprzestrzenił się po świecie z jednego punktu na ziemi (monogenizm), czy z wielu (poligenizm), czy ten ostatni fakt spowodował różnice między ludźmi, czy wyniknęły one z innych przyczyn (klimat, ukształtowanie terenu, rodzaj pożywienia, krzyżowanie ras), lub może decydowały o tym jakieś pierwotne przyczyny leżące w danej rasie. Dociekano, czym jest dziedziczność i jaką rolę odgrywa, czy pierwsi ludzie byli czarni, ile ras tworzy cały rodzaj ludzki. Kontynuowano dążenie do klasyfikowania ras podług wyróżniających je cech fizycznych. Powstawały teorie, które miały wykazać trwałość bądź zmienność ras. Zastanawiano się czy zjawiska społeczne można wyjaśniać poprzez biologiczne, takie jak czystość rasy, bądź jej zmieszanie. Rozważano czynniki, które mogły powodować postęp ludzkości; pytano, czy były one natury rasowej, intelektualnej (wrodzonej), czy generowało je środowisko naturalne, dociekano, dlaczego jedne

notowano uczestnictwo polskich uczonych w międzynarodowym ruchu naukowym (Wystawa antropologiczna... 1878a, s. 270; 1879b, s. 299; Korzon 1884, ss. 138-152); opisywano dary deponowane w Akademii Umiejętności, jak np. czaszki przywiezione z Peru przez Władysława Klugera, polskiego inżyniera i podróżnika (Nowości. Zagraniczne... 1878, s. 300); wskazywano na publikacje polskich uczonych funkcjonujące w obiegu zagranicznym (Lopaciński 1902, s. 110).

13 Jasiewicz 2011; 2018, ss. 41-60.

14 Skomorowski 1875, ss. 439-452; Hoyer 1876, ss. 169-194; Postępy wiedzy... 1887ab; Waligórski 1973, ss. 130-136.

${ }^{15}$ Krótki pogląd... 1874, ss. 91-94; Spencer 1874, s. 80. 
rasy rozwijają się szybciej od drugich. Zaczęto też doszukiwać się różnic pomiędzy białymi mieszkańcami Europy, wynajdywać „właściwości i znamiona pierwotnych ras" u ówczesnych narodów ${ }^{16}$ i wartościować je podług cech uznawanych za wypływające $z$ rasy.

\section{Antropologia jako dziecko medycyny}

$\mathrm{Na}$ ziemiach polskich pod mianem antropologii jedni rozumieli, podobnie jak uczeni starożytni, opis ludzkiej duszy, drudzy - opis ciała. Wedle neurofizjologa i biologa - Michaliny Stefanowskiej, termin ten oznaczał wszystkie nauki, które miały związek z ludzkim życiem: medyczne, filozoficzne i socjologiczne. Jak uważała ona: „nauka o człowieku w ten sposób pojęta jest niewyczerpana i żaden umysł najbardziej encyklopedyczny nie byłby w stanie objąć całości”"17.

Początkowo naukę poświęconą badaniu dziejów człowieka oraz obserwacjom związanym ze zróżnicowaniem ludzkości określano jako historię naturalną. Wedle Stefanowskiej i Juliana Talko-Hryncewicza (lekarza i antropologa) uczynili to Georges L. de Buffon i Johann F. Blumenbach, a za nimi Marcel de Serres, Armand Quatrefages i Paul Broca ${ }^{18}$. Miała ona traktować o całokształcie zjawisk życia ludzkiego na ziemi. Prócz samouków, w większości tzw. badaczy gabinetowych, badań dokonywali przede wszystkim lekarze na materiale archeologicznym oraz żywym ${ }^{19}$. Medycyna była bowiem jedyną ówcześnie rozwinięta nauką o człowieku ${ }^{20}$, dlatego też początkowo prace antropologiczne skupiały się raczej wokół człowieka jako tworu z dziedziny zoologicznej, który można było badać za pomocą wiedzy lekarskiej. Następująco pisał na ten temat Talko-Hryncewicz:

Antropologia ze wszystkich gałęzi nauk przyrodniczych stoi najbliżej medycyny, bo obie studiują człowieka, chociaż

16 Nusbaum 1893, s. 45.

17 Stefanowska 1891, ss. 9-10.

18 ead., s. 10; Talko-Hryncewicz 1888, s. 549.

19 Lekarzami byli francuscy antropolodzy np. Paul Broca (J.J.T. 1881, ss. 339-340), Paul Topinard; niemieccy: Adolf Bastian; amerykańscy: Samuel G. Morton; polscy Leon Dudrewicz, Wiktor Feliks Szokalski, Mieczysław Kaufman, Julian Talko-Hryncewicz, Władysław Olechnowicz, Izydor Kopernicki, Józef Majer, Edward Loth.

20 Ad. J. C. 1882a, s. 402. 
każda z nich z innego punktu widzenia. Medycyna ma na widoku cele praktyczne, antropologia zaś bada człowieka jako jednostkę zoologiczną. Obie nauki opierają się na tych samych wspólnych podstawach, mianowicie na anatomii, fizjologii, patologii i psychologii ${ }^{21}$.

Zdawano więc sobie sprawę, że jeśli dąży się ku dogłębnemu zbadaniu natury ludzkiej, należy łączyć wiadomości z różnych dziedzin wiedzy lekarskiej. Publicysta Bolesław Dunin pisał, że wszystkie nauki pozwalające odróżnić człowieka od zwierząt i rasy ludzkie pomiędzy sobą stanowią nie tylko część medycyny, ale i zoologii i antropologii ${ }^{22}$. Nie było odosobnionym twierdzenie, że centrum zainteresowań uczonych powinien stanowić człowiek, ale wyłącznie pod względem fizycznym ${ }^{23}$. Jak sądził historyk Kazimierz J. Gorzycki:

(...) antropologia (..) ma na oku jedynie istotę ludzką $\mathrm{w}$ tym znaczeniu, że przez odpowiednie pomiary czaszek, badanie kształtów ciała itp. - dąży do poznania, czy, ile i jakie gatunki - względnie rasy, istnieją w całej ludzkości ${ }^{24}$.

Na łamach czasopism czytelników zapoznawano z praktykami badawczymi paryskiego Towarzystwa Antropologicznego (Société d'Anthropologie de Paris), powstałego w 1859 r., którym kierował Paul Broca $^{25}$. Członkami tego towarzystwa byli także polscy uczeni ${ }^{26}$. Stefanowska powstanie tej instytucji uznała za przełomowe wydarzenie: antropologia oddzieliła się wówczas od zoologii i medycyny i zaczęła funkcjonować jako samodzielna gałą́ wiedzy ${ }^{27}$. Specjalność laboratorium tego Towarzystwa stanowiły badania anatomiczne. $Z$ relacji Stefanowskiej przebijała fascynacja zarówno stosowanymi metodami, jak sekcja i dysekcja dokonywane na „trupach”, jak i rozpoznaniem

${ }^{21}$ Talko-Hryncewicz 1888, s. 552.

${ }^{22}$ Dunin 1882a, s. 146.

23 Słów kilka... 1874, s. 100.

${ }^{24}$ Gorzycki 1895, s. 225.

25 Uczeni polscy uważali go za twórcę nowożytnej antropologii, zob. Talko-Hryncewicz 1888, s. 552; Stefanowska 1891, s. 10; Gorzycki 1898, s. 61.

26 Abramowicz 1975, ss. 79-80.

27 Stefanowska 1891, s. 11. 
przeprowadzanym na żywych ludziach. Pisano, że „dzięki podróżnym i dobrej woli osób miejscowych, na świeżych okazach nie zbywa"28. Te „świeże okazy” były to m.in. sprowadzane do Europy grupy ludzi różnego pochodzenia, na przykład, jak ich ówcześnie określano, Indianie czy Eskimosi ${ }^{29}$. Tworzono i eksponowano, często podczas wystaw światowych a także przy ogrodach zoologicznych, „wioski dzikusów”, które uważano za wielką atrakcję. Część ze sprowadzanych ludzi już jako „trupy” służyła do przeprowadzania badań ${ }^{30}$. Z takiej okazji korzystali lekarze - antropolodzy, także na ziemiach polskich ${ }^{31}$. Wedle relacji Dunina, to m.in. badania anatomiczne przyczyniły się do rozróżnienia ras ludzkich. Jeszcze bowiem w połowie XIX w. w naukach medycznych przyjmowano, że wszystkie organy u ludzi zbudowane są jednakowo. Podbudowę dla takich twierdzeń stanowiła „prawowierna doktryna o pochodzeniu ludzkości od pierwszej pary osadzonej w raju”. Tymczasem anatomia, jak się to wówczas zdawało - potwierdziła fizyczne różnice pomiędzy rasami ${ }^{32}$. Podobnie wysoko ceniono kraniologię. Jak pisał publicysta,

(...) wobec trudności posiadania trupów świeżych z ras obcych i trudności w przesyłce całkowitych szkieletów, doniosłość kraniologii w naukach antropologicznych łatwo się daje wyjaśnić. Ze wszystkich kości szkieletu jedna czaszka zapoznaje nas z protoplastami najodleglejszej przeszłości; bez jej znajomości moglibyśmy zaledwie stawiać hipotezy o rasach przedhistorycznych. Kraniologia za

${ }^{28}$ Dunin 1882b, s. 162.

${ }^{29}$ Dziś terminów tych już się raczej nie używa. W pierwszym przypadku szerzej akceptowalne stały się takie jak np. Native Americans w USA czy First Nations w Kanadzie. W drugim, nazwa została zastapiona rodzimym terminem Inuici.

30 Siemiradzki 1894, s. 81.

31 F.S. 1883, ss. 769-770; Dudrewicz 1884, ss. 353-356. Te, organizowane przez cały sztab impresariów, objazdy po stolicach i większych miastach Europy (zob. np. The Invention of Race...2014; Demski 2020, ss. 202-232) szczególnie dla polskich uczonych, którzy pozbawieni byli finansowego wsparcia ze strony rządów zaborczych, stanowiły wyjątkową możliwość do przeprowadzania badań antropometrycznych.

32 Współpracownikiem Paula Broki (jako preparator pracowni antropologicznej Szkoły Nauk Wyższych w Paryżu) był polski lekarz i antropolog Teofil Chudziński. Po powstaniu styczniowym, w którym uczestniczył, wyemigrował do Paryża. Stworzył podstawy antropologii części miękkich - mózgu, mięśni i trzewi. 
pomocą rekonstytucyi odgaduje typy, które z oblicza ziemi zniknęły $(\ldots)^{33}$.

Niestety, brakło porozumienia między uczonymi na świecie co do metod stosowanych przy pomiarach. Stąd też ich wyników nie można było badać porównawczo. Tak jednak czyniono, co skutkowało nieuprawnionymi wnioskami i teoriami.

Bardzo ważny problem stanowiło badanie zależności między ciałem a duchem. Często przypisywano cechom fizycznym - psychiczne, sądząc, że to te pierwsze determinują drugie. Jak pisano, przedmiotem antropologii powinno być „(...) najwewnętrzniejsze nasze $j a$, stara się ona dociec warunków i praw, jakim podlega fizyczna nasza i duchowa istota" ${ }^{34}$. Lączne traktowanie fizyczności i duchowości za bezzasadne uznawał Ernest Renan, uczony francuski, którego prace były bardzo popularne na ziemiach polskich. Uważał on, że antropologia fizyczna rasę traktuje jako pojęcie czysto zoologiczne. Natomiast badania historyczno-lingwistyczne wskazują na wspólnotę kultury. Obydwa te kierunki badań nie mają więc ze sobą punktów stycznych ${ }^{35}$. Renan pisał:

Spory o rasę nie mają końca, a pochodzi to stąd, że historycy-filologowie i antropologowie-fizjolodzy terminowi „rasa” nadaja dwa całkiem odmienne znaczenia. Dla antropologa termin „rasa” ma to samo znaczenie, które posiada w zoologii; wskazuje on na pochodzenie rzeczywiste, czyli pokrewieństwo. Nauka dziejów i językoznawstwo doprowadzaja natomiast do klasyfikacji zupełnie od klasyfikacji fizjologicznej odmiennej. Pojęcia krótkogłowych i długogłowych nie maja prawa obywatelstwa ani w historii, ani w filologii. Grupa ludzka, która wytworzyła języki i porządek aryjski, składała się już zarówno z krótko-, jak i długogłowych ${ }^{36}$.

Podobnie uważał socjolog Ludwik Gumplowicz porównując zakres badań antropologii i etnologii ${ }^{37}$. Opinie w tych kwestiach były rozbież-

33 Dunin 188b, s. 162.

34 Ad.J.C. 1882 b, s. 414.

35 B. N. 1882, ss. 459-460.

36 Renan 1905, s. 431.

37 Gumplowicz 1884, s. 111. 
ne, co dobrze ilustruje komentarz ideologa Narodowej Demokracji Romana Dmowskiego na temat artykułu Gustave’a Le Bona, „Wpływ rasy na historyę", opublikowanego w Revue Scientifique:

Dając za wygraną w kwestyi powstawania ras, ogólnikowo dopiero wyjaśnionej, Le Bon bierze je tak, jak są, za grupy ludzkie, odznaczające się każda z osobna odrębna fizyognomia duchowa. Należałoby dodać: i konstytucyą fizyczna, ale doszukiwanie się pewnych stałych cech fizycznych, jak kształtu głowy, koloru oczów i włosów, bardzo często zawodzii ${ }^{38}$.

Kształtowaniu się antropologii towarzyszyło więc szereg wątpliwości dotyczących nie tylko zakresu badań, ale i stosowanej terminologii. Wiedza o człowieku wyrastała z wielu źródeł, dochodziło do jej wzajemnego przenikania się i łączenia wyników z różnych pól badawczych. Częstokroć, jak wynika to z cytowanych wypowiedzi, dostrzegano w tego rodzaju syntezach (hipotezach i teoriach) niedające się pogodzić sprzeczności.

\section{Ogląd antropologii zachodniej}

Sama antropologia fizyczna (biologiczna, jak ją określano na Zachodzie), najbliższa medycyny, dzieliła się według szkoły francuskiej na dwie gałęzie. Jedna już wspomniana, dla której podstawą była anatomia, kierowała się ku porównawczemu badaniu zwierząt i ludzi, a także ras ludzkich ${ }^{39}$. Druga skupiała się na cechach zewnętrznych człowieka: kolorze skóry, oczu i włosów, proporcjach ciała i rysach twarzy ${ }^{40}$. Podług nich dzielono ludzkość na rasy. Tak pojmowana antropologia badała więc wyłącznie cechy fizyczne. W latach 80. XIX w. jej zadanie upatrywano nie tyle w dociekaniu kwestii powstania człowieka (zakładano za Charlesem Darwinem, że wywodzi się on od jakiejś niższej formy organicznej), co w szukaniu odpowiedzi na następujące pytania:

${ }^{38}$ R. D. 1888 , s. 292.

39 A. 1889 , s. 467.

${ }^{40}$ Dunin 1882b, s. 162. 
(...) w jaki sposób po powstaniu człowieka rozwinęły się rasy, a wśród tych znowu rozmaite gałęzie i pojedyncze szczepy pomniejsze? (...) skąd pochodzą pojedyncze rasy obecnie żyjące? skąd się wzięły ludy? jaki pomiędzy nimi zachodzi związek $?^{41}$.

Nie było rzeczą łatwą uściślenie zakresu badań antropologicznych, ponieważ na gruncie nauki zachodniej, na której często wzorowali się polscy uczeni, brakowało jasnych ujęć. Relacjonując za Paulem Topinardem, antropologiem francuskim, Bolesław Dunin pisał, że antropologia powinna badać nie tylko fizyczność człowieka, ale także jego stronę psychiczną, moralną:

Bierze go ona z kolebki przeszłości, nagiego, dzikiego, wydającego zaledwie źle artykułowane dźwięki i postępuje za nim obserwując stopniowy jego rozwój moralny i fizyczny od pokolenia do pokolenia (...). Przechodząc od rzeczy prostych do złożonych, od organu do funkcyi, od funkcyi do objawów zewnętrznych bądź indywidualnych, bądź zbiorowych - antropologia spostrzega naprzód dokonywające się zmiany fizyczne, następnie - czyny, będące pierwiastkowo instynktowymi ruchami, w następstwie jednak stające się objawem woli; obserwuje rozwój idej, rodzących się wypadkowo, a ustalających się przez dziedziczność; dochodzi wreszcie do zaznaczenia ogólnych pojęć abstrakcyjnych. Słowem dochodzi do ogółu objawów intelektualnych, do ich rozdziału na zdolności indywidualne, rasowe, towarzyskie, przyrodzone, nabyte itp., to jest do tego wszystkiego, co wchodzi w zakres psychologii (...). Antropologia zajmuje się w ten sposób ze stanowiska historii naturalnej pojedynczym indywiduum, rodziną, rasa, ludzkością; z drugiej strony, psychologia i socyologia również do niej należą $(\ldots)^{42}$.

Wedle przywoływanego Topinarda powinnością antropologii miało być także korzystanie ze zdobyczy tych nauk, które zajmują się

41 Ad.J.C. 1882a, s. 403.

${ }^{42}$ Dunin 1882a, s. 146. 
człowiekiem pod kątem tworzonych przez niego „stowarzyszeń”: szczepów i narodów. Tu za przydatne francuski uczony uważał nie tylko wymieniona już socjologię, ale i archeologię, lingwistykę, historię, mitologię, geografię i etnografię. Tę ostatnią rozumiał jako dziedzinę skoncentrowana ,nad zwyczajami, obyczajami, przemysłem, instytucjami, ideami panującymi itd." ${ }^{43}$. Zdawano sobie jednak sprawę, że różnokierunkowość podejmowanych badań uniemożliwia jednoczesne objęcie całokształtu problematyki. Relacje przekazywane w polskiej prasie świadczyły, że to przede wszystkim uczeni szkoły francuskiej postulowali rozszerzenie zakresu badań antropologicznych, tak by ukazać nie tylko fizyczność człowieka. Według Broki, antropologia powinna mieć za przedmiot zbadanie natury ludzkiej w całości, w szczegółach i w stosunku jej do pozostałej przyrody. Inny przywódca tejże szkoły, Armand de Quatrefages, określiwszy antropologię jako historię naturalną człowieka, dodawał uwagę, że antropolodzy powinni troszczyć się o człowieka nie tylko z jego strony fizycznej: ,umysłowa i moralna dziedzina niemniej wymaga pilnej uwagi badacza"44. Zgadzał się z takim ujęciem uczony niemiecki Rudolf Virchow, który uważał, że wąskie specjalizacje, a więc jednostronne, w większym stopniu mogą być obarczone ryzykiem popełnienia błędu. Był on więc zwolennikiem harmonijnej współpracy pomiędzy przedstawicielami poszczególnych dziedzin wiedzy ${ }^{45}$. Podobnie, a przynajmniej tak to wynika z czasopiśmienniczych relacji, uważali Cesare Lombroso ${ }^{46}$, Friedrich Hellwald oraz Friedrich Müller ${ }^{47}$.

Zdaniem Zygmunta Herynga, ekonomisty o szerokich zainteresowaniach,

w naukach dopiero tworzących się (...) uderza nas od razu brak ścisłych granic przedmiotu, brak metod ustalonych, brak wyraźnie określonego stosunku do innych pokrewnych nauk. Dość np. porównać antropologię Topinarda $z$ antropologia Tylora; socjologię Comte'a z socjologią Spencera, lub etykę Spencera z etyką Wundta, by

${ }^{43}$ Ibidem.

${ }^{44}$ Koskowski 1897 a, s. 676.

${ }^{45}$ Virchow 1875a, s. 10; 1875b, s. 22.

${ }^{46}$ Krzywicki 1886, s. 532.

47 Hellwald 1877, s. 219. 
przekonać się, że cała przepaść nie raz oddziela tu dwa systemy naukowe, objęte wspólną nazwą, a różniące się pomimo tego i punktem wyjścia i użytą w nich metoda i zakresem badań i treścią ${ }^{48}$.

$\mathrm{Z}$ upływem lat wskazana powyżej sytuacja nie uległa zmianie. Uczeni nadal głosili sprzeczne ze sobą poglądy, z tych samych przesłanek wyciagali przeciwstawne wnioski. Warto zacytować jeszcze opinię Bolesława Koskowskiego, ekonomisty z wykształcenia i publicysty, na temat ówczesnego pojmowania antropologii jako nauki, potwierdzająca wyżej już wspomniane opinie. Pisał on następująco:

Zamieszanie terminologiczne, jakie panuje w naukach, dotyczących gatunku ludzkiego (poza obrębem medycznych), nie ma sobie równego. Ten sam przedmiot u jednego z autorów nazywa się historią kultury (Lippert'a Kulturgeschichte der Menschheit), u drugiego socjologia (Letourneau La Sociologie d'apres l'ethnographie), u trzeciego antropologia (Tylor, Antropologia, E. Petri, Antropologia, Waitz Antropologie der Naturvölker), u innego wreszcie nauką o ludach (Peschel, Die Völkerkunde) ${ }^{49}$.

W innym tekście Koskowski kontynuował swój wcześniejszy wywód:

Dla Buckle'a czynniki fizjograficzne maja znaczenie przeważne, ćwiekiem Spencera jest „wojowniczość”, Tarde upatruje wszystko w naśladownictwie i wynalazczości, Marks w czynnikach ekonomicznych, Lapouge w walce ras itd. ${ }^{50}$

Recepcja antropologii zachodniej na ziemiach polskich, choć chaotyczna i wybiórcza, odzwierciedlała ówczesną rozmaitość stanowisk wobec zakresu badań antropologicznych. Świadczyła również o stałym zainteresowaniu polskich elit rozwojem nauki na świecie i o dążeniu do upowszechnienia w społeczeństwie polskim wiedzy na temat tego nurtu badawczego.

\footnotetext{
48 Heryng 1888, s. 63.

${ }^{49}$ Koskowski 1897 a, s. 675.

50 id. 1897b, s. 331.
} 


\section{Polskie próby określenia zakresu badań antropologicznych}

Przypomnijmy, że punkt wyjścia do XIX-wiecznych badań stanowiły różnice między ludźmi, a także zależność cech psychicznych człowieka od jego wyglądu zewnętrznego ${ }^{51}$. Piśmiennictwo naukowe i popularnonaukowe, w ślad za badaczami zachodnimi, dążyło do sprecyzowania celów antropologii i zakresu jej badań. Polscy uczeni również nie zajmowali w tej kwestii jednolitego stanowiska. Zdaniem lekarza i publicysty, Bolesława Lutostańskiego, u progu lat 80. XIX w. „na przemian utożsamiano ją to $\mathrm{z}$ anatomią lub fizjologia, to znów z psychologią, historiozofią lub filologia porównawczą" ${ }^{52}$. Antropologia więc stanowiła

(...) niepowiązaną zbieraninę różnych nauk, dotyczących człowieka. (...). Przyrodnicy (...) lekceważyli wyniki badań psychologicznych oraz zapominali o duchowo-społecznej stronie człowieka i odwrotnie: lingwiści i etnologowie nie uwzględniali fizycznej strony człowieka ${ }^{53}$.

Pośród rozmaitych opinii da się wyodrębnić dwa stanowiska badawcze: przypisywano nauce o człowieku pole badawcze najszersze z możliwych i wtedy wyodrębniano w niej poszczególne działy, lub opowiadano się za tym, by za antropologię właściwą uznać jedynie tę fizyczną. Za pierwszym ujęciem opowiadał się Julian Talko-Hryncewicz. Wyjaśniał on, że:

przez antropologię w dzisiejszym, obszernym tego słowa znaczeniu, rozumiemy naukę o człowieku i wszystkiem tem, co dotyczy tak fizycznej jego budowy, jak również i duchowej strony życia. Odnoszą więc do niej badania fizycznego ustroju człowieka, jego fizjologicznych i psychicznych funkcji życiowych, badania oddzielnych plemion i ras, porównanie ich ustroju, badania porównawcze stosunku człowieka do zwierząt, (...), w końcu badania życia duchowego: wyobrażeń, pieśni, legend, obrzędów, wierzeń,

51 Plemiona ludzkie..., 1863, s. 357; Bogacki, 1881, s. 125.

${ }^{52}$ Lutostański 1881, ss. 266-267.

53 id., ss. 272-273; podobnie na ten temat zob. Duchińska 1878, s. 113. 
(...). Wynika stąd, że antropologia w szerszym znaczeniu jest nauką zbiorową, łącząca w sobie zdobycze rozmaitych gałęzi wiedzy. (...). W pierwszym rzędzie należy postawić anatomię i fizjologię, z któremi znowu ściśle łączą się patologia i psychologia; $w$ drugim zaś etnografię z socjologia, historię, archeologię, geografię, paleontologię, lingwistykę, mitologię, demografię itd. ${ }^{54}$

Oczekiwano, że antropologia będzie

(...) centralizować w sobie wszystkie nauki człowieka dotyczące, tak pod względem anatomicznego jak umysłowego rozwoju i postępu. Tu praca gabinetowa na teoretycznych danych, hipotezach, legendach i domniemaniach nie wystarcza. Materiały niezbędne dla tej nauki, po całej kuli ziemskiej rozproszone, potrzebują studiów porównawczych ${ }^{55}$.

Antropologia miała więc wedle powyższego ujęcia, stać się syntezą wiedzy o człowieku, ukazać go jako ,istotę żywą, myślącą i działająca”, przywrócić jedność ciała i ducha ${ }^{56}$. Szerokość zakresu badań postulowana przez antropologów francuskich spowodowała, że i na ziemiach polskich głoszono konieczność podziału prac pośród „naturalistów”: "Jedni powinni się zająć człowiekiem fizycznym, typami, rasami, ich porównaniem ze zwierzętami; drudzy człowiekiem towarzyskim (...)", następnie jego religia, historia, językiem ${ }^{57}$. Każdy jednak - czy uczony, czy publicysta wyodrębniał nieco inne pola badawcze lub inaczej je nazywał. W sumie jednak każdorazowo miały one objąć całokształt wiedzy o człowieku.

Dla Józefa Majera ${ }^{58}$ oraz Izydora Kopernickiego było jasne, że do „antropologii właściwej” zaliczyć należy „badania i opisy fizycznych właściwości cechujących rasy, szczepy i plemiona rodu ludzkiego, oraz wywód rodowitości i wzajemnego powinowactwa lub odrębności krwi". Natomiast badania „właściwości życia duchowego i bytu narodów” to

54 Talko-Hryncewicz 1888, ss. 547-548.

55 Wystawa antropologiczna... 1878a, s. 270.

56 Lutostański 1876, s. 574

57 Dunin 1882a, ss. 146-147; Talko-Hryncewicz 1888, s. 548.

58 Majer 1874, ss. LXXIV-LXXIX. 
zakres etnologii i etnografii ${ }^{59}$. Michalina Stefanowska podobnie wyróżniła dwie „szkoły antropologiczne” ujmujące człowieka: po pierwsze, z punktu widzenia zwierzęcego jako obiekt dociekań zoologicznych dotyczących jednostki i całego gatunku oraz po drugie, jako całość psychofizyczną i istotę społeczna. Jak jednak zaznaczała,

Nie tu miejsce roztrząsać, który z tych dwu kierunków jest racjonalniejszy; sądzimy wszakże, że w badaniu tak skomplikowanych kwestii podział pracy jest niezbędnym (...); a ponieważ rodzaj ludzki rozpatrywany być powinien z rozlicznych punktów widzenia, przeto antropologia pojęta w bardzo obszernym znaczeniu przedstawia pole do badań zarówno dla przyrodnika, jak dla psychologa i socjologa, praca zaś tym sposobem podzielona i rozłożona na liczne grono pracowników, bez watepienia wyda pożądane rezultaty ${ }^{60}$.

Stefanowska, uznając konieczność wszechstronnego badania człowieka, uważała za ,antropologię właściwa" zoologię człowieka ${ }^{61}$. Podobnego zdania, prócz wspomnianego już Kopernickiego, byli Talko-Hryncewicz ${ }^{62}$ i Kazimierz Daniłowicz-Strzelbicki. Ten ostatni, pierwszeństwo oddając , antropologii zoologicznej”, pisał, że „(...) pokazuje człowieka w stosunku do pozostałych istot organicznych, określając odległości i różnice budowy anatomicznej pomiędzy nim a resztą stworzeń żyjących". Antropolog ten za równie ważną dziedzinę wiedzy uważał antropometrię, która miała badać wszystkie rasy i określać ich wzajemny stosunek. Było to dla Daniłowicza-Strzelbickiego istotne, dlatego że główny cel antropologii pojmował jako „ustalenie cech każdej odmiany rodu ludzkiego"63.

W środowisku polskich uczonych stanowisko to znajdowało oponentów. Jak już wspomniałam, punkt widzenia w tym względzie

59 Kopernicki [1881] 1885, s. 1; zob. też Sokolewicz 1974, ss. 184-187 i Wrońska (1992, ss. 7-20).

${ }^{60}$ Stefanowska 1891, s. 10.

${ }^{61}$ Ale „antropologia właściwa” to wedle Lutostańskiego inaczej „antropologia porównawcza” lub „etnologia anatomiczna i fizjologiczna”, także „,antropologia ogólna” lub ,antropologia fizyczna” (1881, s. 270).

62 Talko-Hryncewicz 1888, s. 548.

${ }_{63}$ Daniłowicz-Strzelbicki 1898, s. 378. 
uzależniony był od wykształcenia danego badacza. Odmiennie ujmował zakres antropologii Władysław M. Kozłowski, filozof i z zamiłowania przyrodnik. Recenzując książkę Ludwika Krzywickiego (1893) pisał następująco:

Antropologia i etnologia są niezawodnie kamieniami węgielnymi socjologii przyrodniczej, tej umiejętności, która dotąd była raczej przedmiotem upragnionym niż dokonanym; dzieło p. Krzywickiego najwięcej zdaje mi się ze wszystkich dotychczasowych usiłowań zbliżyło się do tego czym może być socjologia przyrodnicza, tj. do zarysu fizjologii zbiorowego życia $(\ldots)^{64}$.

Z kolei Ignacy Radliński, filolog klasyczny, religioznawca i historyk, określając antropologię jako „naukę o człowieku jako takim”, uważał, że przedmiot jej badań należy do dwóch światów: tego z którego człowiek powstał, czyli zoologii, i tego, który sam stworzył, czyli socjologii. Pisał następująco:

Wiadomości o tym, co stanowi w człowieku jednostkę ludzka jako osobę i organizm jego; co go łączy z otaczającym go światem ludzkim cechami zewnętrznymi lub go od niego różni; (...) jak te cechy zewnętrzne stały się główną podstawa podziału ludzi jako osobnej całości w przeciwstawieniu (...) do otaczającego ją świata zwierzęcego, i jaki jest ów podział (typy, rasy, szczepy, plemiona, ludy); (...) kiedy, gdzie i w jaki sposób powstał człowiek na ziemi (...) - bierze się z zoologii. Socjologia zajmuje się człowiekiem jako już istotą społeczna, rodzajem ludzkim jako ciałem zbiorowym, stanowiącym społeczeństwo ludzkie. Antropologia stanowi przeto ostatni rozdział w zoologii (...). W stosunku zaś do socjologii, staje się jej podstawa, gdyż dostarcza jej zasadniczych pojęć o tym co stanowi jej przedmiot, co zrzuciwszy nazwy antropologiczne: typu, rasy, szcze$\mathrm{pu}$, plemienia, ludu występuje w niej już pod społecznymi jako rodzina, kasta, naród, państwo, zresztą ludzkośćc ${ }^{65}$.

${ }^{64}$ Kozłowski 1893, s. 604.

${ }_{65}$ Radliński 1900, s. 566. 
Antropologia była wówczas nauką młoda, poszukującą dopiero zakresu badań, metod i narzędzi. Odzwierciedlała ona, także w aspekcie nauczania „lokalne i historyczne okoliczności, które towarzyszyły jej początkom"66. Wpływ na przyjmowane perspektywy badawcze miał także rodzaj wykształcenia badaczy i publicystów. Lekarze najczęściej stali na gruncie zoologii i preferowali ludzką fizyczność jako punkt wyjścia do antropologicznych badań porównawczych. Z kolei historycy i językoznawcy bazowali w swych poszukiwaniach na źródłach kulturowych, lecz wspierali się także kryteriami biologicznymi. Archeolodzy, socjolodzy i psycholodzy najczęściej łączyli materiał pozyskiwany z różnych nauk. Czynił tak Ludwik Krzywicki ${ }^{67}$. Zawdzięczamy mu wiele krytycznych recenzji prac, które wywarły wpływ na ówczesne myślenie o „rodzie ludzkim". O uczonych, badających tę problematykę, nie wyrażał się pochlebnie. Na temat dorobku Cesare Lombroso i Ludwika Gumplowicza pisał, iż główną jego cechę stanowi „hazard naukowy”:

obaj opierają się na faktach, lecz widać, że powzięli wypływające $z$ nich wnioski już przed nagromadzeniem obfitego materiału faktycznego; obaj posiadają niezwykłą śmiałość w wypowiadaniu (...) najbardziej niepopularnych sądów, a jeszcze większą w doprowadzaniu możliwych konsekwencji do ostateczności. (...) odznaczają się stosunkowo małym uwzględnieniem ścisłości w wyrażeniach - u obu łatwo wyszukać mnóstwo zdań przeczących sobie (...). (...) sa w nauce przede wszystkim uczonymi publicystami, z całą właściwą tej grupie namiętnością $(. . .)^{68}$.

Antropologia rodziła się więc i rozwijała w wirze różnorodnych hipotez i teorii. Krzywicki jednak widział wartość omawianych prac w ich „działaniu zapładniającym i fermentującym umysły”. Za mniej istotne uważał to co uczeni głosza, jeśli tylko pobudzali umysły do dociekań i zadawania pytań ${ }^{69}$. Sam postępował dokładnie w wyżej przez siebie

${ }^{66}$ Lévi-Strauss 1970, s. 445.

${ }^{67}$ Omawiając pracę Edwarda B. Tylora (1881) Krzywicki wskazał, że angielski uczony pojmuje antropologię na kształt niemieckiej Kulturgeschichte, podczas gdy on sam określił ją wówczas jako naukę o cechach fizycznych człowieka (1889, s. 462).

${ }^{68}$ Lud. Krzyw. 1888a, s. 414.

69 ibid. 
opisany sposób, kiedy nęciły go perspektywa doskonalenia ludzkości za pomocą antropotechniki (poprzez odpowiednie krzyżowanie) lub teorie Georges'a Vacher de Lapouge’a o wyższości rasy długogłowych blondynów nad krótkogłowymi brunetami ${ }^{70}$.

Jak widać, między uczonymi nie było zgodności co do sposobu traktowania badanego podmiotu - człowieka i jego różnorodności. Dodatkową trudność stanowił fakt, że znaczenie słów „antropologia”, „etnologia" i „etnografia” nie było jednoznaczne na gruncie nauki zachodniej ani polskiej. Inaczej rozumiano te pojęcia w różnych krajach ${ }^{71}$. Szkoła niemiecka utożsamiała antropologię z etnologią (np. Adolf Bastian ${ }^{72}$. Uczeni brytyjscy, za przedmiot antropologii uważając badanie człowieka pierwotnego i jego kulturę oraz oddzielając te dociekania od mających charakter biologiczny, dziedzinę tych badań określali rozmaicie, jako: antropologię społeczną, kulturową, socjologię, etnologię i etnografię ${ }^{73}$. W piśmiennictwie polskim nazwy tych dwóch ostatnich dziedzin często stosowano synonimicznie z terminem ,antropologia”. Równocześnie jednak traktowane były one jako nauki pomocnicze antropologii, obejmujące badanie ,umysłowych objawów i moralnego rozwoju" człowieka (narodu), podczas gdy antropologię rozumiano jako naukę badająca go (lub naród) pod względem fizycznym ${ }^{74}$. Rozwój nauk i usamodzielnianie się poszczególnych dyscyplin spowodowały, że z początkiem XX w. poczęto na ziemiach polskich pod mianem antropologii rozumieć wyłącznie fizyczny zakres badań człowieka ${ }^{75}$. Choć nie zrezygnowano z poszukiwań zależności między ciałem a duchem, to jednak przekonano się, że dokonywane podziały między ludźmi (rasami) podług kryteriów fizycznych i kulturowych nie pokrywają się.

70 id. 1888b, ss. 461-462.

71 Barnard 2006, ss. 31-32; Barth, Gingrich, Parkin, Silverman 2007.

${ }^{72}$ Koskowski 1897a, s. 676. W Niemczech królowała wówczas przede wszystkim antropometria. Uczeni tacy jak m. in. H. Helmholtz, W. Wundt, R. Virchow wskazywali jednak na potrzebę wszechstronnego badania człowieka, jego ciała i ducha (Lutostański 1881, s. 267).

${ }^{73}$ Kuper 1987, ss. 10-11.

${ }^{74}$ Wystawa antropologiczna... 1878b, s. 282; Biegeleisen 1885, ss. 398-399.

75 Loth 1908, s. 690. Toczące się polemiki przyczyniły się z czasem, jeśli nie do ujednolicenia pojęć, to w każdym razie do ich sprecyzowania. Obecnie antropologię w Polsce i na świecie pojmuje się jako interdyscyplinarną dziedzinę nauki, która rozwija się na pograniczu nauk humanistycznych, społecznych i przyrodniczych. 
Nie wykryto zależności między kształtem czaszki i wielkością mózgu a potencjałem intelektualnym czlowieka, tak samo jak i nie stwierdzono wspólnoty typu fizycznego z typem kulturowym (np. wyodrębnionym na podstawie języka).

\section{Zakończenie}

Przedstawione różnice w pojmowaniu celów antropologii, jak i łączenie w jej ramach zarówno badań nad fizycznością człowieka, jak i etnologii, etnografii i socjologii stanowiły cechę charakterystyczną omawianego okresu. Szeroki zakres badań spowodował, że na gruncie polskim poczęto wyodrębniać w antropologii różne kierunki rozmaicie postrzegając ich ważność. Ostatecznie miało to doprowadzić do objęcia zasięgiem badań całokształtu zagadnień związanych z człowiekiem. Największe postępy czyniła na ziemiach polskich „część zoologiczna” antropologii: anatomia porównawcza oraz antropometria. W przypadku tej ostatniej, choć nie było zgodności co do metod pomiarów i znaczenia wymiaru, objętości czy wagi poszczególnych narządów, to jednak łatwość dokonywania takich badań decydowała o postępie prac. Z antropometrii wyłoniła się kraniometria, uznawana za bardzo ważną, jako że badała czaszkę „zawierającą organ myślenia" ${ }^{\text {?76 }}$. Dalszy rozwój antropologii uzewnętrznił się poprzez powstawanie kolejnych specjalizacji w jej ramach, których podłożem były problemy, które ówcześnie usiłowano rozwiązać. Warto w tym miejscu wymienić choćby geografię medyczną (inaczej patologię rasowa), której zadaniem było zdiagnozowanie zdolności poszczególnych ras do aklimatyzacji w różnych strefach geograficznych oraz badanie typowych dla nich chorób ${ }^{77}$; geografię antropologiczna (antropogeografię), w zakres której wchodziły badania nad zależnością

${ }^{76}$ Koskowski 1897a, s. 678; Bugiel 1892, ss. 141-142. Polskie badania antropologiczne ograniczały się w zasadzie do antropometrii, w tym kraniometrii. W prasie publikowano informacje na temat działalności Komisji Antropologicznej Akademii Umiejętności (np. Nowości... 1875, s. 351; Lutostański 1881, s. 265), która koordynowała ówczesne prace antropologiczne (Majer 1874-1886). Wydawany przez Komisję „Zbiór Wiadomości do Antropologii Krajowej” został przekształcony w 1895 r. w pismo zatytułowane „Materiały Antropologiczne, Archeologiczne i Etnograficzne” (1896-1919).

77 Zob. np. Złotnicki 1888, ss. 470-471; Judt 1905, ss. 76-77. 
dziejów człowieka od środowiska geograficznego ${ }^{78}$ oraz antropologię kryminalną, która w pewnych cechach fizycznych i psychicznych człowieka upatrywała skłonności do zbrodni ${ }^{79}$.

Polscy uczeni starali się śledzić rozwój antropologii zachodniej. Publikowali wyniki swych badań naukowych także w periodykach zagranicznych. Z kolei czasopiśmiennictwo popularnonaukowe upowszechniało wiedzę gromadzoną przez nauki o człowieku. Ukazywało ono wielokierunkowość poszukiwań badawczych i towarzyszącą im niepewność co do celu antropologii, zakresu jej badań i metod badawczych. Jednocześnie odzwierciedliło niejednoznaczność stosowanych terminów i różnorodność kontekstów, w których bywały one używane. Bez zaangażowania polskich elit, nie tylko uczonych, ale także działaczy społecznych i publicystów (a wszyscy oni byli pasjonatami), nie byłby możliwy zarówno rozwój nauki polskiej - w ścisłej łączności z zachodnią - jak i zainteresowanie ogółu problematyką antropologiczną.

\section{7. Źródła finansowania artykułu}

Artykuł powstał w ramach projektu grantowego Narodowego Centrum Nauki nr 2016/21/B/HS3/03696.

\section{Bibliografia}

\section{ŹRÓDŁA}

A. 1889: Kronika naukowa. Antropologia. Wymiary organów pokarmowych człowieka białego i murzyna. Wszechswiat 29, s. 467.

Ad.J. C., zob. Cohn Adolf Jakub.

B. N. 1882: Co to jest naród? (Według E. Renana). Prawda 39, ss. 459-460.

Biegeleisen, Henryk 1885: Zadania i metoda etnologii. Wedrowiec 35, ss. 398-399.

Bogacki, Feliks 1881: Tajemnice życia duszy. Prawda 11, ss. 125-126.

Bugiel, Włodzimierz 1892: Zwrot w teoriach ras. Ateneum (III) 7, ss. 138-153.

Cohn, Adolf Jakub 1882a: Darwin i antropologia według R. Virchowa. Prawda 34, ss. 402-404.

${ }^{78}$ Nałkowski 1890ab.

79 Lombroso [1864] 1887; Dr. J. N. 1889b, s. 463. 
Cohn, Adolf Jakub 1882b: O stosunku badań językowych do antropologii. Odczyt dra T. Neuburgera (na zjeździe antropologów). Prawda 35, ss. 414-415.

Daniłowicz-Strzelbicki, Kazimierz 1898: Rozbiory i sprawozdania. Ludwik Krzywicki, „Kurs systematyczny antropologii. I. Rasy fizyczne”, Warszawa 1897 r. Ateneum (I) 2, ss. 375-384.

Dmowski, Roman 1888: Rasa i dzieje. Prawda 25, ss. 291-292.

Dr. J. N., zob. Nusbaum Józef.

Duchińska, Seweryna 1878: Z wystawy paryskiej. Biblioteka Warszawska III, ss. 111-133.

Dudrewicz, Leon 1884: Kilka słów o czerwonoskórcach z pokolenia „Omaha” pod względem antropologicznym. W szeechświat 23, ss. 353-356.

Dunin, Bolesław 1882a: Z antropologii (według M.A. Topinard). Cz. I. Rozwój obecny i stan nauki, Prawda 13, ss. 146-147.

Dunin, Bolesław 1882b: Z antropologii (według M.A. Topinard). Cz. II. Laboratorya i kraniologia, Prawda 14, ss. 161-162.

F. S., zob. Sulimierski, Filip.

Gloger, Zygmunt 1879: Obrazy z zamierzchłych dziejów. Odczyt na rzecz Osad rolnych, w wielkiej Aleksandrowskiej sali ratuszowej w Warszawie. Biblioteka Warszanska II, ss. 143-153.

Gorzycki, Kazimierz J. 1895: O antropologii etnicznej (na podstawie „Ludów” Krzywickiego). Lud I, ss. 225-244.

Gorzycki, Kazimierz J. 1898: Antropologia rasowa. Ludwik Krzywicki. Kurs systematyczny antropologii. I. Rasy fizyczne. Warszawa. Druk K. Kowalewskiego, 1897. Lud IV, ss. 60-79.

Gumplowicz, Ludwik 1884: Najnowszy stan kwestyi rasowej. Prawda 10, ss. 110 $-111$.

Hellwald, Fryderyk 1877: Znaczenie i zadania narodoznawstwa, przełożył z niemieckiego Stanisław Tomaszewski. Prayroda i Pržemysł 19, ss. 219-221.

Heryng, Zygmunt 1888: Notatki ekonomiczne. Glos 6, ss. 63-64.

Hodi, J., zob. Tokarzewicz, Józef

Hoyer, Henryk 1876: Krytyczny pogląd na Darwinizm. Ateneum II, ss. 169-194.

J.J.T. 1881: Paweł Broca. Prawda 29, ss. 339-340.

Judt, Ignacy 1902: Żydzi jako rasa fizyczৃna. Warszawa: S. Wende i S-ka.

Kopernicki, Izydor 1876: Kongres międzynarodowy antropologii i archeologii przedhistorycznej w Peszcie. Warszawa: M. Ziemkiewicz. 
Katarzyna Wrzesińska

Zanim skrystalizował się zakres badań, czyli o rozwoju nauk o człowieku...

Kopernicki, Izydor [1881] 1885: O etnografii i etnologii. Ich pržedmiot, rozwój $i$ znaczenie nankowe, dla Encyklopedii Wychowawczej. Warszawa: W Drukarni J. Sikorskiego.

Korzon, Tadeusz 1884: Kongres antropologiczny we Wrocławiu. Ateneum IV, ss. $138-152$.

Koskowski, Bolesław 1897a: Antropologia współczesna. Głos 28, ss. 675-681.

Koskowski, Bolesław 1897b: Rozwój socjologii. I. Zwrot do badań socjologicznych. Gtos 13, ss. 330-334.

Kozłowski, Władysław M. 1893: Rozbiory i sprawozdania. Ateneum IV, ss. 604-611.

Krótki pogląd na naukę o pochodzeniu istot żyjących. 1874: Wẹdrowiec, 214, ss. 91-94.

Krzywicki, Ludwik 1886: Teorya Cezara Lombroso, I. Prawda 45, ss. 532-533.

Krzywicki, Ludwik 1888a: Socyologia (Gumplowicza). Prawda, 35, ss. 413-414.

Krzywicki, Ludwik 1888b. Zagadnienia antropologiczne. Prawda, 39, ss. 461-462.

Krzywicki, Ludwik 1889: Ed. B. Tylor. Prawda, 39, ss. 462-463.

Krzywicki, Ludwik 1893: Ludy. Zarys antropologii etnicænej, Warszawa: K. Kowalewski.

Lombroso, Cesare [1864] 1887: Geniusz i obłakanie w zwiazku z. medycyna sadowa krytyka $i$ historiq, przełożył J. L. Popławski. Warszawa: Skład Główny w Księgarni Gebethnera i Wolffa.

Loth, Edward 1908: Cele i zadania antropologii współczesnej. Wszechświat 44, ss. 689-693.

Lud. Krzyw., zob. Krzywicki, Ludwik

Lutostański, Bolesław 1876: Cel i zadanie spółczesnej antropologji. Kosmos I, ss. 565-574.

Lutostański, Bolesław 1881: Antropologia. [W:] J.T. Lubomirski; E. Stawiski; S. Przystański; J.K. Plebański (red.), Encyklopedia wychowawcza, t. I. (ss. 262-275). Warszawa: Skład Główny w Księgarni Gebethnera i Wolffa.

Łopaciński, Hieronim 1902: Sprawozdania i krytyka. A selected bibliography of the anthropology and ethnology of Europe, by William Z. Ripley Ph.D. (Boston 1899, str. 10+160). Wista XVI (1), ss. 109-110.

Majer, Józef 1874: Posiedzenie komisyi antropologicznej dnia 16 maja. Rozprawy i sprawozdania z posiedzeń Wydzialu Matematyczno-Prayrodniczego Akademii Umiejętności. T. I, ss. LXVI-LXXXIV. Kraków: Akademia Umiejętności.

Majer, Józef; Kopernicki, Izydor 1874-1886: Zbiór wiadomości do antropologii krajowej. T. I-IX. Kraków: Drukarnia Uniwersytetu Jagiellońskiego. 
Materialy Antropologiczৃno-Archeologiczৃne i Etnograficz̨ne. 1896-1919. T. 1-14. Kraków: Nakładem Akademii Umiejętności. Skład Główny w Księgarni Spółki Wydawniczej Polskiej.

Nałkowski, Wacław 1890a: Neoritterianizm w geografii. [1]. Prawda, 26, ss. 305-306 .

Nałkowski, Wacław 1890b: Neoritterianizm w geografii. [II]. Prawda, 27, ss. 317-319 .

Nowości. Zagraniczne 1875: Wedrowiec 308, s. 351.

Nowości. Zagraniczne 1878: Wedrowiec, 97, s. 300.

Nusbaum, Józef 1889: Najnowsze zdobycze na polu kryminalnej antropologii. Prreglad Tygodniowy, 39, ss. 463-464.

Nusbaum, Józef 1893: Dobór naturalny w rozwoju ustroju społecznego. Biblioteka Warszawska IV, ss. 44-55.

Plemiona ludzkie. 1863: Wedrowiec 23, ss. 356-358.

Postępy wiedzy ludzkiej w ciąu ostatnich lat pięćdziesięciu (1836-1886), podług Grant Allen'a. 1887a: Gtos 26, ss. 405-406.

Postępy wiedzy ludzkiej w ciąu ostatnich lat pięćdziesięciu (1836-1886), podług Grant Allen'a. 1887b: Gtos 27, ss. 422-423.

R. D., zob. Dmowski, Roman.

Radliński, Ignacy 1900: Powstanie antropologii jako nauki odrębnej. Ws şechświat 36, ss. 565-570.

Radliński, Ignacy 1902: Historia nanki o czlowieku (Historia Antropologii). T. I. Czasy przedhistoryczne i starożytne, cz. I. Warszawa: Wydawnictwo „Poradnika dla czytających książki”; Warszawa: P. Laskauer.

Renan, Ernest [1882]1905: Co to jest naród? Odczyt wygłoszony w Sorbonie d. 11 marca 1882 r. (przeł. S. Dobrowolski). Wista XIX (4), ss. 422-440.

Siemiradzki, Józef 1894: Mieszkańcy Ziemi Ogniowej. Wszechśmiat 6, ss. 81-83.

Skomorowski, Tadeusz 1875: Z dziedziny przyrodoznawstwa. Biblioteka Warszawskea II, ss. 439-452.

Słów kilka o zadaniach antropologii. 1874: Wẹdrowiec 216, ss. 100-102.

Spencer, Herbert 1874: Nauka o społeczeństwach, Tygodnik Ilustrowany, nr 318, ss. $79-80$.

Stefanowska, Michalina 1891: Kilka słów o dzisiejszym stanie nauczania antropologii. Wszechśniat 1, ss. 9-10. 
Sulimierski, Filip 1883: Lud przedhistoryczny a jednak współczesny. W szechświat 49, ss. 769-772.

Talko-Hryncewicz, Julian 1888: Antropologia w ogóle i w zastosowaniu do kraju naszego. Wisła II (3), ss. 547-562.

Tokarzewicz, Józef 1873: Szósty międzynarodowy kongres antropologii przedhistorycznej, w Bruxelli 1872. Biblioteka Warszawska II, ss. 82-95.

Tylor, Edward B. 1881: Anthropology. An Introduction to the Study of Man and Civilisation. London: Macmillan.

Virchow, Rudolf 1875a: Pierwotna ludność Europy. Odczyt. Prayroda i Przemyst 1, ss. 8-10.

Virchow, Rudolf 1875b: Pierwotna ludność Europy. Odczyt. Prayroda i Przemyst 2, ss. 22-24.

Wystawa antropologiczna w Paryżu. Opisał dr. Silex. 1878a: Wedrowiec 95, s. 270.

Wystawa antropologiczna w Paryżu. (Dalszy ciąg.). 1878b We drowiec 97, s. 299.

Złotnicki, Antoni 1888: Zalew świata przez rasę europejska, We drowiec 40, ss. 470 -471 .

\section{OPRACOWANIA}

Abramowicz, Andrzej 1975: Societe d'anthropologie et d'ethnographie polonaise de Paris (1878-?). Kwartalnik Historii Nanki i Techniki 20/1, ss. 79-88.

Barnard, Alan 2006: Antropologia. Zarys teorii i historii (przeł. S. Szymański). Warszawa: PIW.

Barth, Fredrik; Gingrich Andre; Parkin Robert; Silverman Sydel 2007: Antropologia. Jedna dyscyplina, çtery tradycje: brytyjska, niemiecka, francuska i amerykańska. (przeł. J. Tegnerowicz). Kraków: Wydawnictwo Uniwersytetu Jagiellońskiego.

Bielicki, Tadeusz; Krupiński, Tadeusz; Strzałko Jan 1987: Historia antropologii w Polsce. Przeglad Antropologiczny 53 (1-2), ss. 3-28.

Demski, Dagnosław 2020: Spaces of Modernity: Ethnic Shows in Poznań, 1879_ -1914, East Central Europe 47 (2-3), pp. 202-232 https://doi.org/10.30965/ $\underline{18763308-04702003}$

Hołda-Róziewicz, Henryka 1969: Prace antropologiczne Ludwika Krzywickiego na tle początków antropologii polskiej. Kwartalnik Historii Nanki i Techniki 4, ss. 649-659.

Jasiewicz, Zbigniew 2011: Poczqtki polskiej etnologii i antropologii kulturowej (od końca XVIII wieku do roku 1918). Poznań: Instytut im. Oskara Kolberga, Komitet Nauk Etnologicznych PAN. 
Jasiewicz, Zbigniew 2018: Skąd, z czym i w jaki sposób etnografia/etnologia/ antropologia pojawiła się. Lud 102, ss. 42-83.

Kuper, Adam 1987: Miedzy charyzma a rutynq. Antropologia brytyjska 1922-1982 (przeł. K. Kaniowska). Lódź: Wydawnictwo Lódzkie.

Lévi-Strauss, Claude 1970: Antropologia strukturalna (przeł. K. Pomian). Warszawa: PIW.

Malinowski, Andrzej 1988: Sześćdziesięciolecie działalności Polskiego Towarzystwa Antropologicznego. Przeglad Antropologiczny 1-2, ss. 7-14.

Popowicz, Kamil 2009: Lamarkizm spoteczny a rasizm i engenika we Francji. Warszawa: Wydawnictwa Uniwersytetu Warszawskiego.

Bancel, N.; David, T.; Thomas, D. (eds.). 2014 The Invention of Race. Scientific and Popular Representation. Routlege: New York-Abington. DOI:

https://doi.org/10.4324/9781315813318.

Waligórski, Andrzej 1973: Antropologiczna koncepcja człowieka. Warszawa: PWN.

Wrońska, Jolanta 1992: Definicje etnografii i etnologii w polskich encyklopediach z drugiej połowy XIX i na początku XX wieku. Etnografia Polska 36 (1), ss. 7-20. 